\title{
Determining Children's Primary School Readiness Level
}

\author{
Yalçın Bay \\ Anadolu University, Turkey \\ Dondu Neslihan Bay \\ Eskisehir Osmangazi University, Turkey
}

Doi:10.19044/ejes.v7no4a6 URL:http://dx.doi.org/10.19044/ejes.v7no4a6

\begin{abstract}
This study aimed to determine the primary school students' readiness for school and analyze it according to some socio-demographic characteristics Readiness can be defined as having the necessary precondition behaviors and reaching the desired maturity level for the child to be able to learn and develop. The level of readiness of the child is important in achieving the desired goals in education. In the study, the school readiness levels of the first grade primary school students were determined and examined regarding to their personal characteristics. The conducted research contributes to the related literature in the aspect of introducing how ready children in Turkey, which has a different education system and culture, are for school in the beginning stages of primary school. The research was conducted in general survey model, one of the quantitative research methods. 402 students attending the first grade of primary school in Eskişehir province participated in the study. The "Primary School Readiness Scale" (Canbulat \& Kırıktaş, 2016) used in the study was filled out by the teachers for each participating student. The children's school readiness levels were examined in the cognitive, affective, psychomotor and self-care skills sub-dimensions of the scale. Descriptive statistics were calculated in the analysis of data, Confirmatory Factor Analysis (CFA) was performed; Mann Whitney U and Kruskal Wallis H test, ANOVA, Scheffe Post-Hoc tests were used. As a result of the research, it was found that primary school readiness levels of the following students' groups were significantly higher ( $\mathrm{p}<0.05$ ): the students who had preschool education compared to the students who had not; the students who are 72-84 months old compared to the students who are 60-72 months old; the students whose mothers' education level are high compared to the students whose mothers have lower education and the students whose fathers are working compared to the students whose fathers are not working. Also, significant differences were found in primary school readiness level of some subgroups in the following dimension: girls are
\end{abstract}


significantly more ready in affective dimension; the readiness of the students whose mother is working is higher in cognitive dimension; and students whose father had a university education and more are more ready in cognitive, affective and psychomotor dimensions $(\mathrm{p}<0,05)$. The results obtained from the research were discussed in line with the related literature.

Keywords: School Readiness; Preschool; Primary School; Cognitive; Affective.

\section{Introduction}

The period in which the student starts primary school is seen as an important milestone in the life of the student. If the student had not received preschool education, he/she starts to receive education from adults other than their peers and family for the first time. This change in the student's life can lead to consequences where he/she can achieve or fail to fulfill the tasks and responsibilities. The positive or negative experiences of the student who started primary school play an important role in achieving a productive life of education. This research aims to reveal the primary school readiness of the students in Turkey and the effect of some variables on the readiness level.

Readiness, which is also expressed in different terms such as school maturity, preparedness (Erkan \& Kirca, 2010), is defined as the language and thinking skills that the child should have before starting school, as well as the skills required for adaptation and success (Noel, 2010). These skills are the skills that show that the child matured in terms of emotional, social, physical and cognitive development areas that should be possessed before starting school (Gündüz and Çalışkan, 2013; Yörükoğlu, 1993). The child, who is ready for school, gets sufficient development with the support of family, environment and school and possesses the necessary knowledge, skills and behaviors (Dinç, 2013). Hence, in addition to the developmental characteristics, some factors affect the child's school readiness, such as family and environmental conditions (Stocks \& Oshio, 2009). Regarding school readiness, several studies focusing on the gender and age variables of the child were found (e.g., Ar1 \& Özcan, 2014; Erkan \& K1rca, 2010; Öztürk \& Uysal, 2013; Yoleri \& Tanış, 2014) and these studies revealed a positive relationship between school readiness and the increase in the age of the child (e.g., Vandell, Nenide, \& Winkle, 2006). In Turkey, the child's chronological age is considered as the basic criterion to start primary school (Canbulat and Y1ldızbaş, 2014). After it has been decided that the duration of primary school education will be four years in the 2012-13 academic year, the age range of starting primary school has been set as 60-66 months (MoNE, 2012). However, it was possible to postpone schooling for up to 71 months with a doctor's report indicating that the child was not developmentally ready for 
school (Başbuğ \& Kurnaz, 2013; Canbulat \& Yıldızbaş, 2014). Studies showed that children who have started primary school according to chronological age have problems in terms of school readiness (Canbulat, 2010; Öztürk \& Uysal, 2013). Due to these problems, the age of starting primary school was changed in 2019 after the decision taken by the Ministry of National Education and the upper limit was changed to 69 months (MoNE, 2019).

Another variable that has a significant effect on the child's school readiness level is preschool education (Koçyiğit \& Saban, 2014; Yavuzer, 2010; Yoleri \& Tanış, 2014). In Turkey, all children are expected to receive preschool training. Planned and systematic preschool education aiming to support children's developmental areas and to improve their skills plays an important role in the child's primary school readiness level (Bütün Ayhan and Aral 2007; Umek, Kranjc, Fekonja, \& Bajc, 2008). According to the studies, it is seen that in terms of basic skills and development areas, children having preschool education have a higher level of school readiness compared to children without preschool education. (e.g., Cinkılıç, 2009; Erkan and Kırca, 2010; Esaspehlivan, 2006; Işık, Akosmanoğlu and Bilir, 2015; Magnuson, Meyers, Ruhm and Waldfogel, 2004; Unutkan, 2003; Yazıc1, 2002; Yoleri and Tanış, 2014). Polat and Yavuz (2014) reported that the duration of preschool education increases children's self-esteem, self-concept, mathematical skills, drawing skills, phonological skills, social-emotional development and cognitive-linguistic development. Since the preparation to primary school requires the systematic acquisition of necessary skills and supporting all development areas of the children (Oktay and Unutkan, 2005), preschool education is an important opportunity to be used for the school readiness of disadvantaged children (Polat \& Yavuz, 2016; Umek et al., 2008).

Families have a significant effect on the children's school readiness as much as Preschool education. The behaviors and attitudes of the family towards the child are quite effective in making the child ready for education life (Akbag, 2007). The family must fulfill its responsibilities to ensure that the child will be prepared for school from the moment of birth (Dinç, 2013). The socio-economic level of families is a major factor in the effectiveness of a child's environment. Working parents have higher income and, therefore, can live under better circumstances. A supportive home environment, which can be established with better economic conditions, affects the child's primary school readiness significantly (Britto, 2012; Ferguson, Bovaird and Mueller, 2007). Isaac and Magnuson (2011) concluded that there was a positive relationship between the increase in the economic conditions and educational levels and school maturity of the child. The increase in the education level of the family also positively affects children's school readiness (Alakoç Pirpir et al., 2016; Erkan, 2011; Erkan \& Kırca, 2010). The research conducted by Ar1 
and Özcan (2014) on the effect of school maturity on the literacy learning of first-year pupils revealed that the increase in the educational level of the parents increased reading maturity in children.

Starting primary school is an important event that requires the child to be ready for education life, and some factors have an impact on the readiness of the child. The child who starts primary school should be supported in case of deficiencies or inadequacies. This support is only possible by determining how much the child is ready for primary school. This research is considered to be important in terms of revealing the extent of the children's primary school readiness and the factors that affect readiness levels.

\section{Objective of the Study}

The purpose of the study was to determine the school readiness level of primary school first grade students, and in line with this purpose, subobjectives such as determining the level of school readiness of children according to their gender, age, education levels and working status of their parents were determined.

\section{Method}

The research was conducted in general survey model, one of the quantitative research methods. This research is based on a relational screening model, which is a research model that identifies the existence and / or the degree of the change between 2 or more variables (Karasar, 2016). "Primary School Readiness Scale" (Canbulat \& Kırıktaş, 2016) was used in the study. The children's school readiness levels were examined in the cognitive, affective, psychomotor and self-care skills sub-dimensions of the scale. Descriptive statistics were calculated in the analysis of the data. Confirmatory Factor Analysis (CFA) was performed; Mann Whitney U and Kruskal Wallis $\mathrm{H}$ test, ANOVA, Scheffe Post-Hoc tests were used.

\section{Participants}

In this study, in the 2019-2020 academic year, it was carried out in Eskişehir city center, in 3 state primary schools, with 402 students attending the first year of primary school. In the study, 15 primary school 1st-grade classrooms taught by 15 primary school teachers that are in 3 state primary schools were determined, and data was collected. Within the scope of the research, the distribution of 402 students whose primary school readiness levels were determined based on the easily accessible sampling method, which was not selected, was examined according to some demographic characteristics, and the results are shown in Table 1. 


\section{Data Collection Tools}

As a data collection tool; With the Personal Information Form, "School Readiness Scale" developed by Canbulut and Kırıktaş in 2016 was used.

\section{Personal Information Form}

Personal Information Form was used to collect some demographic information of the children participating in the study. The form contains information on children's preschool education, age, gender, education and working status of their parents. Demographic information about students and parents was given by the classroom teachers, with the permission of the parents.

The table showing the demographic information of the participants is given below;

Table 1. Distribution of Participants

\begin{tabular}{|c|c|c|c|}
\hline \multirow[b]{3}{*}{$\begin{array}{l}\text { Preschool } \\
\text { Education }\end{array}$} & \multirow{3}{*}{$\begin{array}{l}\text { Had Preschool Education } \\
\text { Didn't have Preschool } \\
\text { Education }\end{array}$} & \multirow{3}{*}{$\begin{array}{l}\mathrm{N} \\
374 \\
28\end{array}$} & \multirow{3}{*}{$\begin{array}{l}\% \\
93.0 \% \\
7.0 \%\end{array}$} \\
\hline & & & \\
\hline & & & \\
\hline \multirow{2}{*}{ Gender } & Female & 199 & $49.5 \%$ \\
\hline & Male & 203 & $50.5 \%$ \\
\hline \multirow{2}{*}{ Age } & 6 years-old & 284 & $70.6 \%$ \\
\hline & 7 years-old & 118 & $29.4 \%$ \\
\hline \multirow{4}{*}{ Mother's Education } & Primary School & 79 & $19.7 \%$ \\
\hline & Secondary School & 88 & $21.9 \%$ \\
\hline & High School & 117 & $29.1 \%$ \\
\hline & University, Postgraduate & 118 & $29.4 \%$ \\
\hline Mother's & Housewife & 254 & $63.2 \%$ \\
\hline Employment status & Employed & 148 & $36.8 \%$ \\
\hline \multirow{4}{*}{ Father's Education } & Primary School & 35 & $8.7 \%$ \\
\hline & Secondary School & 72 & $17.9 \%$ \\
\hline & High School & 162 & $40.3 \%$ \\
\hline & University, Postgraduate & 133 & $33.1 \%$ \\
\hline Father's & Non-employed & 16 & $4.0 \%$ \\
\hline Employment status & Employed & 386 & $96.0 \%$ \\
\hline
\end{tabular}

Regarding Table 1, 93\% of the children received preschool education, $50.5 \%$ were boys, $70.6 \%$ were six-years-old, $29.4 \%$ have university/post graduated mothers, the mothers of $63.2 \%$ of them were employed, $33.1 \%$ have university/post graduated fathers, the fathers of $96 \%$ of them were employed. 


\section{Primary School Readiness Scale}

Primary School Readiness Scale was developed by Canbulat and Kirıktaş (2016) by collecting data from 620 first-year pupils. The assessment tool consists of 33 items and four sub-dimensions: cognitive skills, affective skills, psychomotor skills and self-care skills. The scale was found to be a valid and reliable tool with an internal consistency coefficient of.991. The scale items consist of the following Likert type options: "(5) completely sufficient, (4) sufficient, (3) moderately sufficient, (2) partially sufficient and (1) not sufficient". The lowest score that can be obtained from the scale is 33, and the highest score is 165 . The high score attained from the scale can be interpreted as high-level school readiness of the first-year students, whereas the low score indicates low-level school readiness.

The sub-dimensions of the scale can be described as follows:

Cognitive skills; cognitive skills that are expected to be acquired by the child in school readiness,

Affective skills; affective skills that are expected to be acquired by the child in school readiness.

Psychomotor skills: psychomotor skills that are expected to be acquired by the child in school readiness.

Self-care skills: self-care skills that are expected to be acquired by the child in school readiness

The Ministry of National Education aims for 60-72 month-old students who receive pre-education to gain cognitive, affective, psychomotor and selfcare skills (MEB, 2013).

Cognitive skills:

$\checkmark$ Completes the missing human picture by drawing arms and legs.

$\checkmark$ Complete 10-25 piece jigsaw puzzle.

$\checkmark$ Creates new shapes by combining geometric shapes.

$\checkmark$ Groups 6-10 objects according to any of their properties.

$\checkmark$ Establishes a relationship between groups of objects from 1 to 10 and numbers.

$\checkmark$ Adds using items 1 to 10 .

$\checkmark$ Subtracts using objects 1 to 10 .

$\checkmark$ Shows half and whole objects.

$\checkmark$ List the numbers from 1 to 20 .

$\checkmark$ Describes how to match, associate, group and order.

$\checkmark$ Establishes cause and effect relationships.

$\checkmark$ Briefly remembers the details in a picture shown.

$\checkmark$ Predicts what might happen after an event.

$\checkmark$ Tells the similarities and differences between objects.

$\checkmark$ Tells the positions of objects in a sequence with respect to each other. 
$\checkmark$ Uses benchmarking expressions that report quantities.

$\checkmark$ Tells the days of the week in order.

$\checkmark$ Counts rhythmically up to 20 .

$\checkmark$ Tells the names of different time periods of the day.

$\checkmark$ He pays attention to his work.

$\checkmark$ Reason towards the solution of the problem situation.

$\checkmark$ Creates graphics using concrete objects.

$\checkmark$ Reads the object graphic.

$\checkmark$ Creates patterns of three items. (MEB, 2013).

Affective skills:

$\checkmark$ Tells his/her home address.

$\checkmark$ Tells the parent's phone number.

$\checkmark$ Reveals his/her feelings.

$\checkmark$ Explains the emotional expressions of others.

$\checkmark$ Expresses himself/herself in original ways.

$\checkmark$ Follows the rules.

$\checkmark$ When necessary, explains the rules to others.

$\checkmark$ Fulfills given responsibility.

$\checkmark$ Has self confidence.

$\checkmark$ Adapts to new and unfamiliar situations.

$\checkmark$ Communicates easily with new individuals.

$\checkmark$ Behaves in line with their goals.

$\checkmark$ Control your emotions.

$\checkmark$ Undertakes leadership when necessary (MEB, 2013).

Psychomotor skills:

$\checkmark$ Jumps running over the obstacle.

$\checkmark$ Makes the gallop movement rhythmically.

$\checkmark$ Bounces rhythmically.

$\checkmark$ One foot leaps and moves 2-3 m.

$\checkmark$ Throws the ball over the shoulder with one hand.

$\checkmark$ Rolls the ball off the ground with one hand.

$\checkmark$ Hits the target at a certain distance.

$\checkmark$ Bounces the ball 5-6 times on the ground.

$\checkmark$ Skips rope.

$\checkmark$ Stays in balance using different parts of his body.

$\checkmark$ Stands for 9-10 seconds on one leg.

$\checkmark$ Rolls forward without help (Tumbles.).

$\checkmark$ Makes various movements one after another, accompanied by music and rhythm. 
$\checkmark$ Creates 2-3 piece compositions using soft materials.

$\checkmark$ When the pattern is shown, it folds the paper diagonally.

$\checkmark$ Looking at the model, draws a circle, triangle, square and rectangle.

$\checkmark$ Draws horizontal, vertical, curved, and curved lines and creates a new shape from them.

$\checkmark$ Holds the pen correctly.

$\checkmark$ Copies numbers 1-5 (MEB, 2013).

Self-care skills:

$\checkmark$ Brushes own teeth.

$\checkmark$ Washes and dries their face.

$\checkmark$ Washes own body.

$\checkmark$ Meets the toilet needs on their own.

$\checkmark$ Takes and fulfills responsibility in daily work.

$\checkmark$ Chooses clothes suitable for weather conditions.

$\checkmark$ Takes off their clothes and dresses on their own.

$\checkmark$ Buttons on/off and snaps on/off their clothes.

$\checkmark$ Ties their own shoes.

$\checkmark$ Uses the cooking tools like an adult.

$\checkmark$ Holds dinner plates or serving tray.

$\checkmark$ Uses the cleaning materials correctly.

$\checkmark$ Realizes situations that may create danger. (MEB, 2013).

Before proceeding with the factor analysis of students' school readiness, the test known as Cronbach's Alpha test in the literature was performed to check the reliability of the measurement method, and the results are given below;

Table 2. Results of Reliability Analysis for School Readiness Scale

Cronbach's Alpha Number of Items

,991 33

Regarding Table 2, the reliability coefficient of the 33-item School Readiness Scale, which was applied to 402 students in total, was 0.991 $(99.1 \%)$. This level shows that the reliability of the measurement method is highly sufficient, and the compliance required for the analysis is ensured. The analyzes conducted for item-total correlations showed that item correlations were around 0.8 and at reasonable levels. Confirmatory Factor Analysis (CFA) results are given below; 
"Primary School Readiness Scale" (Canbulat \& Kırıktaş, 2016) was used in the study. The children's school readiness levels were examined in the cognitive, affective, psychomotor and self-care skills sub-dimensions of the scale. The Confirmatory Factor Analysis (CFA) was performed because a previously developed scale was used to analyze the data.

Table 3. CFA Goodness of Fit Test Values for School Readiness Scale

\begin{tabular}{|c|c|c|c|}
\hline $\begin{array}{l}\text { Fit } \\
\text { Parameter }\end{array}$ & $\begin{array}{l}\text { Fit } \\
\text { Parameter } \\
\text { Statistics }\end{array}$ & $\begin{array}{l}\text { Acceptable } \\
\text { Values }\end{array}$ & Good Fit Values \\
\hline RMSEA & 0.15 & $\begin{array}{l}0.05 \leq \text { RMSEA } \leq \\
0.08\end{array}$ & $0 \leq \mathrm{RMSEA} \leq 0.05$ \\
\hline SRMR & 0.05 & $0.05 \leq \mathrm{SRMR} \leq 0.08$ & $0 \leq \mathrm{SRMR} \leq 0.05$ \\
\hline GFI & 0.57 & $0.90 \leq \mathrm{GFI} \leq 0.95$ & $0.95 \leq \mathrm{GFI} \leq 1.00$ \\
\hline AGFI & 0.51 & $0.85 \leq \mathrm{AGFI} \leq 0.90$ & $0.90 \leq \mathrm{AGFI} \leq 1.00$ \\
\hline CFI & 0.97 & $0.90 \leq \mathrm{CFI} \leq 0.95$ & $0.95 \leq \mathrm{CFI} \leq 1.00$ \\
\hline NFI & 0.97 & $0.90 \leq \mathrm{CFI} \leq 0.95$ & $0.95 \leq \mathrm{CFI} \leq 1.00$ \\
\hline
\end{tabular}

RMSEA: Root Mean Square Error of Approximation, NFI: Normed Fit Index, GFI: Goodness of Fit Index, AGFI: Adjusted Goodness of Fit Index, CFI: Comparative Fit Index

In the evaluation of the indexes, the following criteria were taken into account: $0.90 \leq \mathrm{CFI} \leq 0.95$ acceptable fit, $0.95 \leq \mathrm{CFI} \leq 1.00$ good fit, $0.05 \leq$ SRMR $\leq 0.10$ acceptable fit, $0 \leq \mathrm{SRMR} \leq 0.05$ good fit, $0.05 \leq \mathrm{RMSEA} \leq$ 0.08 acceptable fit, $0 \leq$ RMSEA $\leq 0.05$ good fit, $0.90 \leq \mathrm{GFI} \leq 0.95$ acceptable fit, $0.95 \leq \mathrm{GFI} \leq 1.00$ good fit, $0.85 \leq \mathrm{AGFI} \leq 0.90$ acceptable fit, $0.90 \leq \mathrm{AGFI}$ $\leq 1.00$ good fit. Being equal to or higher than 0.30 is the criterion taken into consideration while evaluating standardized factor loads. The CFA PATH diagram showing the standardized factor loads is given below. 


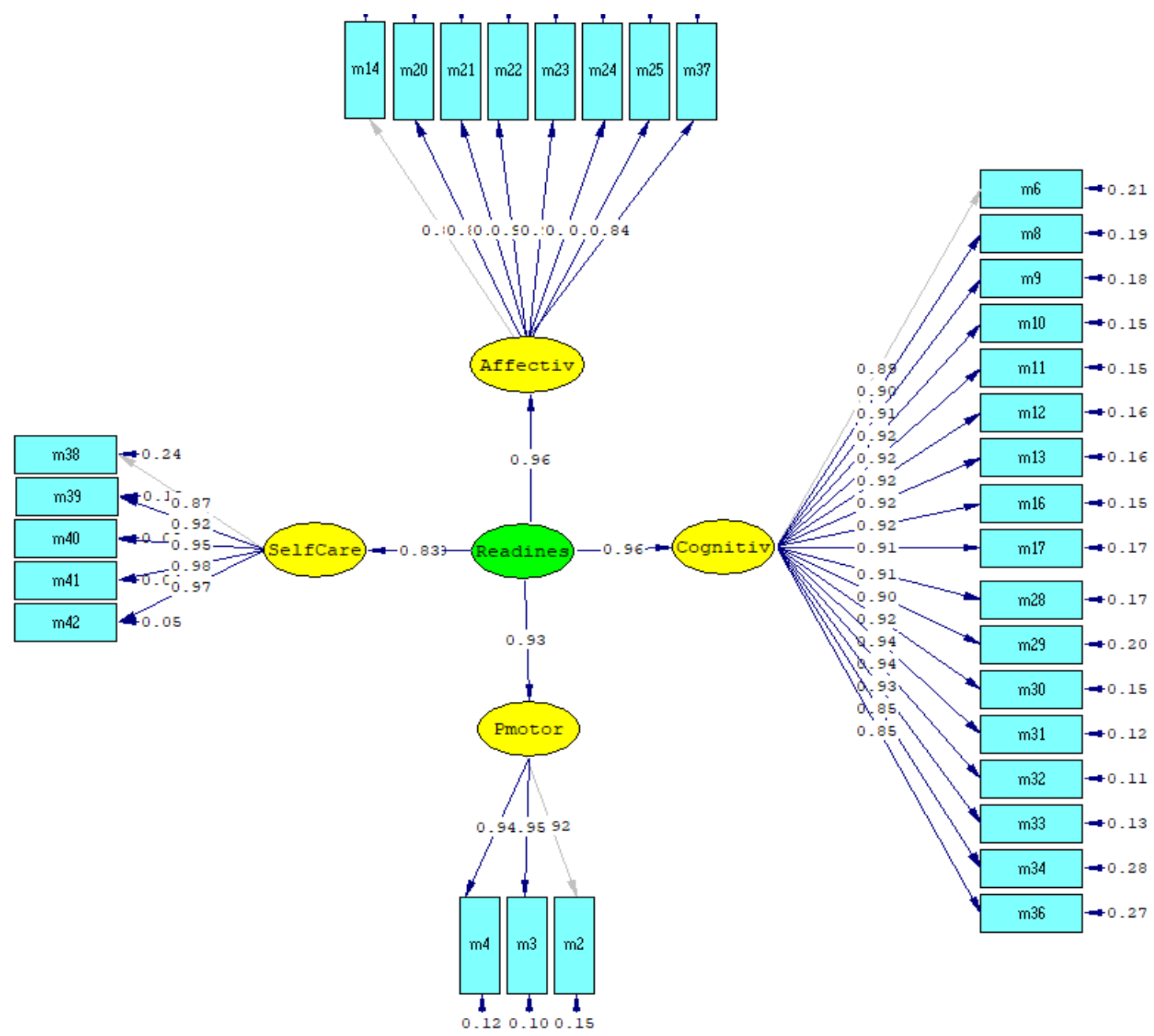

Test results obtained for the reliability and validity of the dimensions are given below;

Table 4. Reliability of Sub-dimensions of Readiness Scale

\begin{tabular}{ll}
\hline Dimension & Cronbach's Alfa \\
\hline Cognitive Skills & 0.987 \\
Affective Skills & 0.970 \\
Self-Care Skills & 0.974 \\
Psychomotor Skills & 0.954 \\
Overall Questionnaire & 0.991 \\
\hline \hline
\end{tabular}


The Cronbach's alpha coefficients of the sub-dimensions of the scale were found to be between 0.954-0.987. Accordingly, the measurement tool used in the study was determined to be highly reliable (Büyüköztürk, 2010).

In this section, personal information, confirmatory factor domain, and Cronbach's alpha coefficient about the students participating in the research are tabulated and interpreted. Cronbach's alpha coefficient was determined to be reliable. The scale's sub-dimensions are cognitive skills, affective skills, psychomotor skills, and self-care skills.

\section{Data Collection}

In the study, the measurement tool was applied to the children who started their first year in the fall semester of 2019-2020 academic year by 15 teachers working in 3 different primary schools in September. Necessary permissions were obtained before initiating the study, and school administrators and teachers were met voluntarily. The teachers evaluated the readiness of the children based on their observations about the children and filled the scale.

\section{Data Analysis}

The data were analyzed with SPSS 20 package program. The normality of the variables was checked by Kolmogorov-Smirnov and Shapiro-Wilk tests. Using the 0.05 significance level, if $p<0,05$, the variables were assumed to be non-normally distributed. Non-parametric tests were used for variables that didn't show normal distribution. The results were also evaluated at the 0.05 significance level; a significant relationship was assumed if $\mathrm{p}<0.05$, whereas the lack of substantial relationship was assumed if $p>0.05$.

To determine the tests that are statistically appropriate to apply, the new dimensions obtained from the scores given to the questions were tested in terms of normality.

Table 5. Normality Test Results for Sub-dimensions of Readiness Scale

\begin{tabular}{|c|c|c|c|c|c|c|}
\hline & \multicolumn{3}{|c|}{ Kolmogorov-Smirnov } & \multicolumn{3}{|l|}{ Shapiro-Wilk } \\
\hline & Test Statistic & S.d. & p. & Test Statistic & S.d. & p. \\
\hline Cognitive Skills & .115 & 402 & $*<.000$ & .922 & 402 & $*<.000$ \\
\hline Affective Skills & .121 & 402 & $*<.000$ & .911 & 402 & $*<.000$ \\
\hline $\begin{array}{l}\text { Psychomotor } \\
\text { Skills }\end{array}$ & .189 & 402 & $*<.000$ & .896 & 402 & $*<.000$ \\
\hline Self-Care Skills & .203 & 402 & $*<.000$ & .847 & 402 & $*<.000$ \\
\hline
\end{tabular}


Regarding Table 5, the zero-hypothesis, which assumes that the calculated dimensions show normal distribution, is rejected with $95 \%$ reliability according to Kolmogorov \& Simonov Test. Therefore, nonparametric methods were preferred for different tests.

The descriptive analysis was conducted to determine the school readiness of the first-year pupils, and the arithmetic means and standard deviations of the scores were calculated. Confirmatory factor domain and Cronbach's alpha coefficient were tabulated and interpreted on the "Primary School Readiness Scale." Cronbach's alpha coefficient was determined to be reliable. The sub-dimensions of the scale were determined.

Kruskal-Wallis-H and Mann-Whitney-U tests were used to determine whether children's school readiness differed significantly in terms of preschool education, gender, age, and educational and working status of their parents.

\section{Results}

Descriptive statistics related to the dimensions of the primary school readiness scale of the children participating in the study are given in Table 6.

Table 6. Descriptive Statistics for for Sub-dimensions of Readiness

\begin{tabular}{lllll}
\hline \hline & Minimum & Maximum & Mean & $\begin{array}{l}\text { Standard } \\
\text { Deviation }\end{array}$ \\
\hline Cognitive Skills & 17.00 & 85.00 & 67.7164 & 13.54439 \\
Affective Skills & 8.00 & 40.00 & 32.2786 & 6.30259 \\
Psychomotor Skills & 3.00 & 15.00 & 11.9204 & 2.53920 \\
Self-Care Skills & 5.00 & 25.00 & 21.1169 & 3.91222 \\
Number & of & & & \\
Observations (N) & 402 & & & \\
\hline \hline
\end{tabular}

Regarding primary school readiness levels of the children displayed in Table 6 , it can be said that the averages are quite high. In other words, children are quite ready to start school in terms of cognitive, affective, psychomotor and self-care skills.

The results of independent sample Mann-Whitney U and KruskalWallis $\mathrm{H}$ tests used to check whether these dimensions are affected by the related demographic variables are given below.

Students' readiness levels; Mann-Whitney $\mathrm{U}$ and Kruskal-Wallis $\mathrm{H}$ tests were applied to determine whether there was a significant difference according to their pre-school education status, gender and age. The results obtained are given in tabular form and interpreted.

Firstly, the results of independent sample t-test, which test the significance of the difference between the averages of the groups according to the preschool education status, are given below; 
Table 1. Descriptive Statistics for the Sub-dimensions According to Student's Preschool Education Status

\begin{tabular}{|c|c|c|c|}
\hline Dimensions & Preschool Education & Mean & $\begin{array}{l}\text { Std. } \\
\text { Deviation }\end{array}$ \\
\hline \multirow[b]{2}{*}{ Cognitive Skills } & Had Preschool Education 374 & 68.9733 & 12.53304 \\
\hline & $\begin{array}{l}\text { Didn't have Preschool } 28 \\
\text { Education }\end{array}$ & 50.9286 & 15.50610 \\
\hline \multirow[b]{2}{*}{ Affective Skills } & Had Preschool Education 374 & 32.7326 & 5.86425 \\
\hline & $\begin{array}{l}\text { Didn't have Preschool } 28 \\
\text { Education }\end{array}$ & 26.2143 & 8.59525 \\
\hline \multirow[b]{2}{*}{$\begin{array}{l}\text { Psychomotor } \\
\text { Skills }\end{array}$} & Had Preschool Education 374 & 12.1043 & 2.40806 \\
\hline & $\begin{array}{l}\text { Didn't have Preschool } 28 \\
\text { Education }\end{array}$ & 9.4643 & 2.98741 \\
\hline \multirow[b]{2}{*}{ Self-Care Skills } & Had Preschool Education 374 & 21.2861 & 3.68039 \\
\hline & $\begin{array}{l}\text { Didn't have Preschool } 28 \\
\text { Education }\end{array}$ & 18.8571 & 5.87344 \\
\hline
\end{tabular}

According to Table 7, it was observed that school readiness scores of the children who received preschool education are higher than the children who did not. Mann-Whitney-U test was used to determine whether this difference was significant.

Table 2. Mann-Whitney-U Test Results According to Preschool Education

\begin{tabular}{|c|c|c|c|c|}
\hline & Cognitive Skills & Affective Skills & $\begin{array}{l}\text { Psychomotor } \\
\text { Skills }\end{array}$ & Self-Care Skills \\
\hline Mann-Whitney U & 1962.500 & 2742.000 & 2643.000 & 3865.500 \\
\hline $\mathrm{Z}$ & -5.567 & -4.246 & -4.509 & -2.401 \\
\hline p. & $*<0,001$ & $*<0,001$ & $*<0,001$ & $.016^{*}$ \\
\hline
\end{tabular}

Regarding Table 8, the null-hypothesis claiming that the difference between the group means is statistically insignificant is rejected in cognitive skills, affective skills, psychomotor skills and self-care skills dimensions at a 95\% confidence level $(\mathrm{p}<0.05)$. Accordingly, it can be said that preschool education is statistically significant on all sub-dimensions of readiness scale. Therefore, the children who receive preschool education are more ready for school.

The results of the test analyzing whether the subscales of readiness scale differ significantly in terms of the gender are shown below; 
Table 9. Descriptive Statistics for the Sub-dimensions According to Student's Gender

\begin{tabular}{lllll}
\hline Dimensions & Gender & $\mathrm{N}$ & Mean & Std. Deviation \\
\hline \multirow{2}{*}{ Cognitive Skills } & Female & 199 & 68.5327 & 13.00884 \\
& Male & 203 & 66.9163 & 14.03559 \\
\hline \multirow{2}{*}{ Affective Skills } & Female & 199 & 32.9497 & 5.76628 \\
& Male & 203 & 31.6207 & 6.73685 \\
\hline \multirow{2}{*}{ Psychomotor Skills } & Female & 199 & 12.0402 & 2.40966 \\
& Male & 203 & 11.8030 & 2.66079 \\
\hline \multirow{2}{*}{ Self-Care Skills } & Female & 199 & 21.1658 & 3.82148 \\
& Male & 203 & 21.0690 & 4.00806 \\
\hline
\end{tabular}

Regarding the school readiness of children according to gender, it is seen that girls' school readiness score is higher than boys. Mann-Whitney-U test was used to determine whether this difference seen in favor of girls constitutes a significant difference between genders.

Table 10. Mann-Whitney-U Test Results According to Student's Gender

\begin{tabular}{lllll}
\hline \hline & Cognitive Skills & Affective Skills & $\begin{array}{l}\text { Psychomotor } \\
\text { Skills }\end{array}$ & Self-Care Skills \\
\hline Mann-Whitney U & 18750.000 & 17857.000 & 19254.500 & 20000.000 \\
Z & -1.254 & -2.030 & -.836 & -.177 \\
p. & .210 & $.042^{*}$ & .403 & .859 \\
\hline \hline
\end{tabular}

$$
* p<0.05 ; H_{0}: \mu_{1}=\mu_{2}
$$

Regarding Table 10, the null-hypothesis claiming that the difference between the group means is statistically insignificant is only rejected in affective skills dimension at a 95\% confidence level $(p<0.05)$. According to this, it can be said that gender is effective on the affective skills dimension of readiness scale, whereas it is ineffective on the other dimensions. In other words, the school readiness level of the girls differs significantly from boys in the affective dimension.

The results of the Mann-Whitney-U test analyzing the significance of the difference between the students' age groups' means for related dimensions are shown below; 
Table 11. Descriptive Statistics for the Sub-dimensions According to Student's Age Groups

\begin{tabular}{lllll}
\hline \hline Dimensions & Age Groups & $\mathrm{N}$ & Mean & Std. Deviation \\
\hline \multirow{3}{*}{ Cognitive Skills } & 6 years-old & 284 & 65.1127 & 13.00834 \\
& Total & 402 & 67.7164 & 13.54439 \\
\hline \multirow{2}{*}{ Affective Skills } & 6 years-old & 284 & 30.9577 & 6.14072 \\
& 7 years-old & 118 & 35.4576 & 5.52329 \\
& Total & 402 & 32.2786 & 6.30259 \\
\hline \multirow{2}{*}{ Psychomotor } & 6 years-old & 284 & 11.3803 & 2.39621 \\
Skills & 7 years-old & 118 & 13.2203 & 2.40774 \\
& Total & 402 & 11.9204 & 2.53920 \\
\hline \multirow{2}{*}{ Self-Care Skills } & 6 years-old & 284 & 20.2887 & 4.01777 \\
& 7 years-old & 118 & 23.1102 & 2.78207 \\
& Total & 402 & 21.1169 & 3.91222 \\
\hline \hline
\end{tabular}

Table 11 shows that children's school readiness increases as their age increases. The significance of the difference between the scores was tested by Kruskal-Wallis test.

Table 3 Mann Whitney-U Test Results According to Student's Age Groups

\begin{tabular}{lllll}
\hline \hline & Cognitive Skills & Affective Skills & $\begin{array}{l}\text { Psychomotor } \\
\text { Skills }\end{array}$ & Self-Care Skills \\
\hline Mann-Whitney U & 9854.50 & 9380.50 & 9300.500 & 9521.00 \\
Z & $-6,560$ & $-7,019$ & $-7,247$ & $-7,085$ \\
p. & $*<0,001$ & $*<0,001$ & $*<0,001$ & $*<0,001$ \\
\hline \hline
\end{tabular}

$$
{ }^{*} p<0.05 ; H_{0}: \mu_{1}=\mu_{2}
$$

Regarding Table 12, the null-hypothesis claiming that the difference between the group means is statistically insignificant is rejected in cognitive skills, affective skills, psychomotor skills and self-care skills dimensions at a 95\% confidence level $(\mathrm{p}<0.05)$. According to this, it can be said that the age factor is statistically significant on all sub-dimensions of readiness scale. Therefore, children's school readiness level significantly increases as their age increases.

The results of the Kruskal-Wallis $H$ test analyzing the effect of mother's education and working status on relevant variables are shown below; 
Table 13. Descriptive Statistics for the Sub-dimensions According to Student's Mothers Education

\begin{tabular}{|c|c|c|c|c|}
\hline Dimensions & Mother's Education & $\mathrm{N}$ & Mean & $\begin{array}{l}\text { Std. } \\
\text { Deviation }\end{array}$ \\
\hline \multirow{5}{*}{ Cognitive Skills } & Primary School & 79 & 61.2785 & 15.27352 \\
\hline & Secondary School & 88 & 66.7614 & 13.23961 \\
\hline & High School & 117 & 67.8376 & 12.80555 \\
\hline & $\begin{array}{l}\text { University, } \\
\text { Postgraduate }\end{array}$ & 118 & 72.6186 & 11.28642 \\
\hline & Total & 402 & 67.7164 & 13.54439 \\
\hline \multirow{5}{*}{ Affective Skills } & Primary School & 79 & 29.1899 & 7.45254 \\
\hline & Secondary School & 88 & 32.0000 & 5.90149 \\
\hline & High School & 117 & 32.6068 & 5.92621 \\
\hline & $\begin{array}{l}\text { University, } \\
\text { Postgraduate }\end{array}$ & 118 & 34.2288 & 5.28732 \\
\hline & Total & 402 & 32.2786 & 6.30259 \\
\hline \multirow{5}{*}{$\begin{array}{l}\text { Psychomotor } \\
\text { Skills }\end{array}$} & Primary School & 79 & 10.9873 & 2.81704 \\
\hline & Secondary School & 88 & 11.5114 & 2.50055 \\
\hline & High School & 117 & 12.1282 & 2.45138 \\
\hline & $\begin{array}{l}\text { University, } \\
\text { Postgraduate }\end{array}$ & 118 & 12.6441 & 2.21697 \\
\hline & Total & 402 & 11.9204 & 2.53920 \\
\hline \multirow{5}{*}{ Self-Care Skills } & Primary School & 79 & 19.9114 & 4.83892 \\
\hline & Secondary School & 88 & 20.8750 & 3.97351 \\
\hline & High School & 117 & 21.1197 & 3.39412 \\
\hline & $\begin{array}{l}\text { University, } \\
\text { Postgraduate }\end{array}$ & 118 & 22.1017 & 3.41788 \\
\hline & Total & 402 & 21.1169 & 3.91222 \\
\hline
\end{tabular}

Regarding school readiness, according to the mother's educational status, an increase was observed in children's school readiness scores as mothers' education level increases towards university and master's degrees. The significance of the difference between the scores was tested by KruskalWallis test.

In this section, ANOVA test was applied to determine the effects of parents 'education level and working status on students' school readiness. According to the ANOVA results, the significant difference levels between 
the education levels and working conditions of the parents and the readiness levels of the students were transferred to the tables and interpreted.

The ANOVA results showing the relationship between mother education level on children's perception of readiness, is given in the table below;

Table 14. ANOVA Results in Terms of Mother's Education Level

\begin{tabular}{|c|c|c|c|c|c|c|}
\hline & & $\begin{array}{l}\text { Sum of } \\
\text { Squares }\end{array}$ & $\mathrm{df}$ & $\begin{array}{l}\text { Mean } \\
\text { Square }\end{array}$ & $\mathrm{F}$ & Sig. \\
\hline \multirow[t]{3}{*}{ Cognitive Skills } & $\begin{array}{l}\text { Between } \\
\text { Groups }\end{array}$ & 6192,056 & 3 & 2064,019 & 12,193 & $*<, 000$ \\
\hline & $\begin{array}{l}\text { Within } \\
\text { Groups }\end{array}$ & 67371,616 & 398 & 169,275 & & \\
\hline & Total & 73563,672 & 401 & & & \\
\hline \multirow[t]{3}{*}{ Affective Skills } & $\begin{array}{l}\text { Between } \\
\text { Groups }\end{array}$ & 1221,908 & 3 & 407,303 & 11,022 & $*<, 000$ \\
\hline & $\begin{array}{l}\text { Within } \\
\text { Groups }\end{array}$ & 14706,888 & 398 & 36,952 & & \\
\hline & Total & 15928,796 & 401 & & & \\
\hline \multirow[t]{3}{*}{$\begin{array}{l}\text { Psychomotor } \\
\text { Skills }\end{array}$} & $\begin{array}{l}\text { Between } \\
\text { Groups }\end{array}$ & 150,349 & 3 & 50,116 & 8,191 & $*<, 000$ \\
\hline & $\begin{array}{l}\text { Within } \\
\text { Groups }\end{array}$ & 2435,104 & 398 & 6,118 & & \\
\hline & Total & 2585,453 & 401 & & & \\
\hline \multirow[t]{3}{*}{ Self-Care Skills } & $\begin{array}{l}\text { Between } \\
\text { Groups }\end{array}$ & 234,396 & 3 & 78,132 & 5,268 &, $001 *$ \\
\hline & $\begin{array}{l}\text { Within } \\
\text { Groups }\end{array}$ & 5903,109 & 398 & 14,832 & & \\
\hline & Total & 6137,505 & 401 & & & \\
\hline
\end{tabular}

When the table above is analyzed, it can be seen that the hypothesis, which claims that the difference between the group averages in terms of mother's education level is statistically insignificant, can be rejected in all dimensions ( $p<0.05$ ). Therefore, it can be said with $95 \%$ confidence that the education level of the mother is statistically significant in children's perception of readiness.

In order to determine from which groups causes the difference between the group averages according to the mother's education status, the results of the Scheffe Post-Hoc test that is conducted are given in the table below; 
Table 15. Scheffe Post-Hoc Test Results by Mother's Education Level

95\%

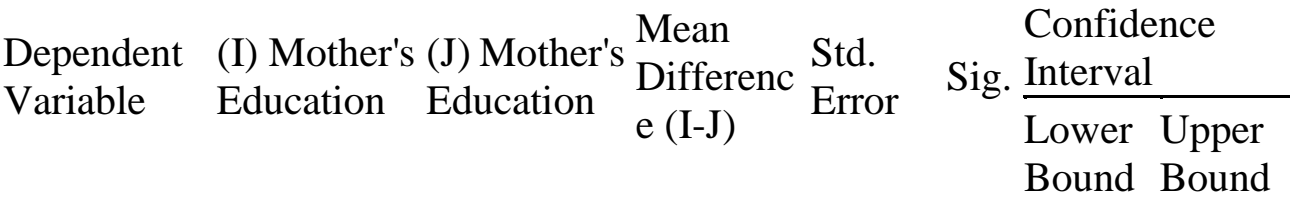

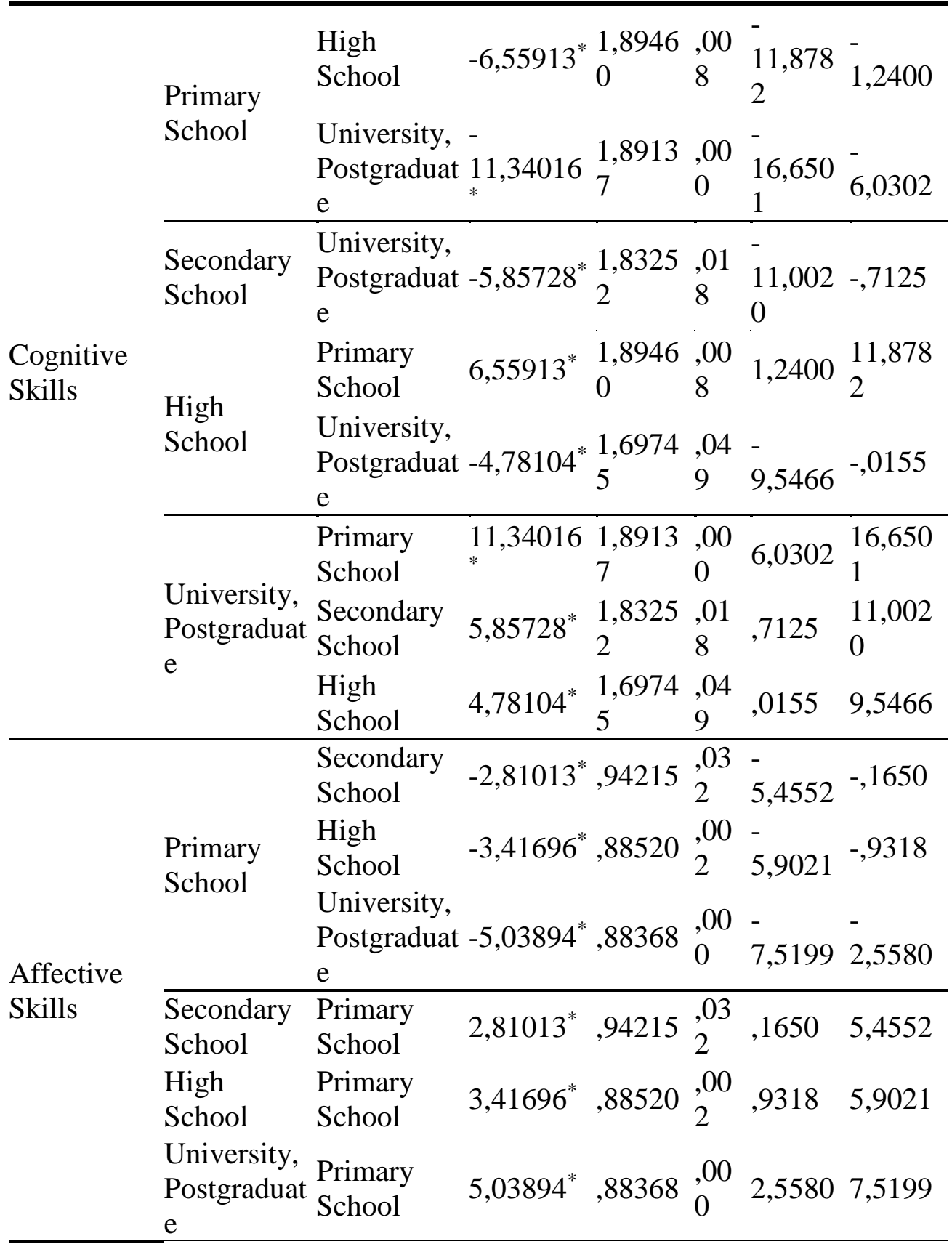




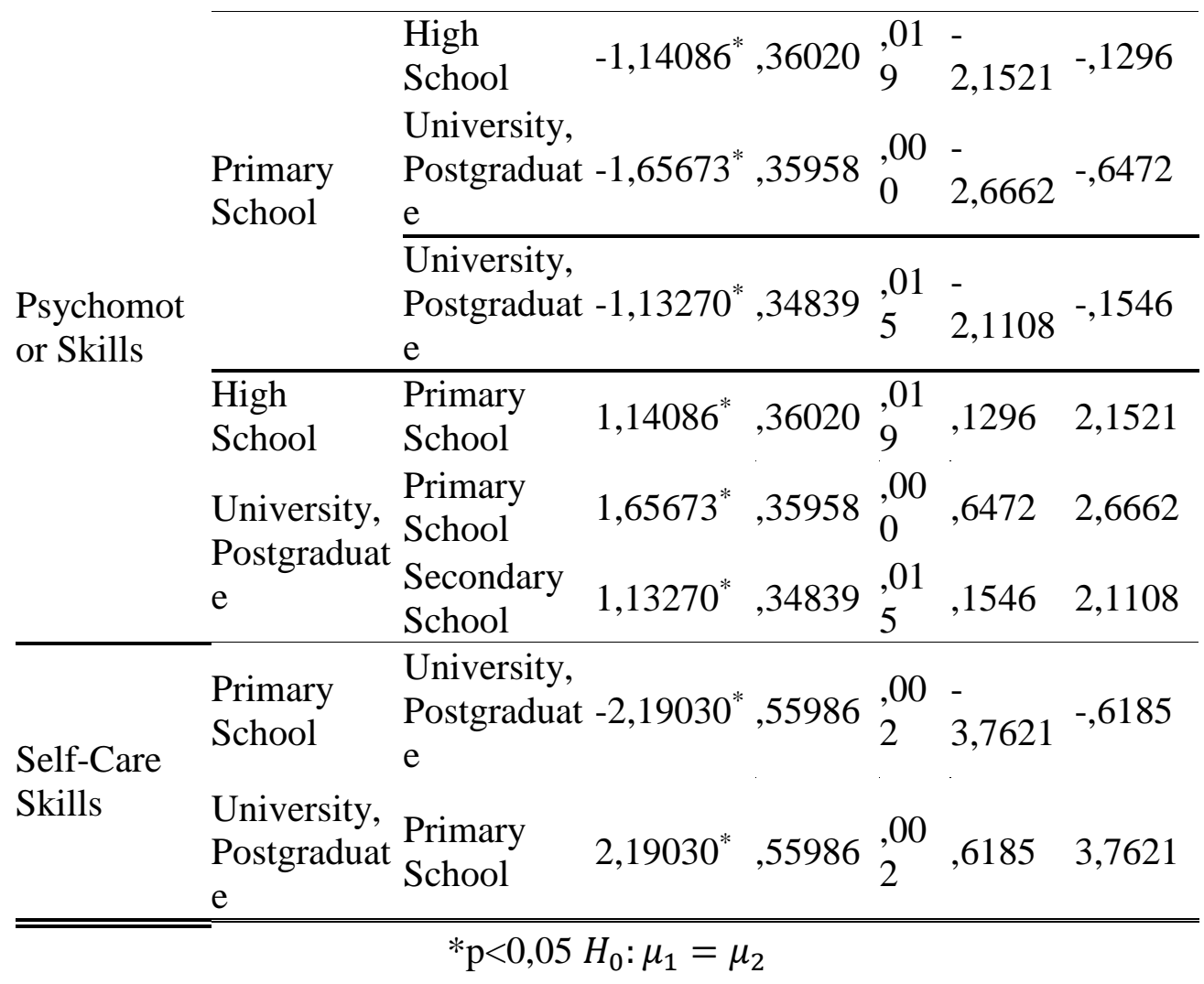

When Table 15 is examined for mother education level, according to cognitive skills sub-dimension; university education level is creating significant difference level from other education levels. This significiency can say for other sub-dimensions too.

The results of the test analyzing the effect of the mother's employment status on relevant variables are shown below;

Table 16. Descriptive Statistics for the Sub-dimensions According to Student's Mothers Employment Status

\begin{tabular}{lllll}
\hline \hline Dimensions & Mother's & N & Mean & Std. Deviation \\
\hline \multirow{2}{*}{ Eognitive Skills } & Housewife & 254 & 66.7244 & 13.60869 \\
& Employed & 148 & 69.4189 & 13.30695 \\
\hline \multirow{2}{*}{ Affective Skills } & Housewife & 254 & 31.9449 & 6.39022 \\
& Employed & 148 & 32.8514 & 6.12829 \\
\hline \multirow{2}{*}{ Psychomotor Skills } & Housewife & 254 & 11.7520 & 2.61296 \\
& Employed & 148 & 12.2095 & 2.38833 \\
\hline
\end{tabular}




\begin{tabular}{lllll}
\hline \multirow{2}{*}{ Self-Care Skills } & Housewife & 254 & 21.0039 & 3.84121 \\
& Employed & 148 & 21.3108 & 4.03699 \\
\hline \hline
\end{tabular}

As can be seen in Table 16, the school readiness level of the children with working mothers is higher. Mann-Whitney-U test was used to determine whether this ratio makes a significant difference between the groups.

Table 16. Mann-Whitney-U Test Results according to the Mother's Employment status

\begin{tabular}{lllll}
\hline \hline & Cognitive & \multirow{2}{*}{ Affective Skills } & Psychomotor Skills & Self-Care Skills \\
\hline Skills & 16477.000 & 16903.000 & 16732.500 & 17585.500 \\
$\mathrm{Z}$ & -2.081 & -1.701 & -1.894 & -1.119 \\
$\mathrm{p}$. & $.037 *$ & .089 & .058 & .263 \\
\hline \hline & & $* \mathrm{p}<0.05 ; H_{0}: \mu_{1}=\mu_{2}$
\end{tabular}

Regarding Table 16, the zero-hypothesis claiming that the difference between the group means is statistically insignificant is rejected only in the cognitive skills dimension at a 95\% confidence level $(\mathrm{p}<0.05)$. Therefore, it is not valid for the remaining dimensions. In other words, it is seen that children are significantly more ready to school in terms of cognitive skills dimension according to the working status of their mother.

The results of the test analyzing the effects of father's education and working status on relevant variables are shown below;

Table 17. Descriptive Statistics for the Sub-dimensions According to Student's Fathers Education

\begin{tabular}{|c|c|c|c|c|}
\hline Dimensions & Father's Education & $\mathrm{N}$ & Mean & $\begin{array}{l}\text { Std. } \\
\text { Deviation }\end{array}$ \\
\hline \multirow{5}{*}{ Cognitive Skills } & Primary School & 35 & 59.4857 & 15.07700 \\
\hline & Secondary School & 72 & 65.5417 & 14.39282 \\
\hline & High School & 162 & 67.3210 & 13.39679 \\
\hline & $\begin{array}{l}\text { University, } \\
\text { Postgraduate }\end{array}$ & 133 & 71.5414 & 11.53027 \\
\hline & Total & 402 & 67.7164 & 13.54439 \\
\hline \multirow{3}{*}{ Affective Skills } & Primary School & 35 & 28.8000 & 7.32763 \\
\hline & Secondary School & 72 & 31.5139 & 6.69453 \\
\hline & High School & 162 & 32.3580 & 6.19418 \\
\hline
\end{tabular}




\begin{tabular}{lllll} 
& University, & 133 & 33.5113 & 5.55635 \\
& Postgraduate & 402 & 32.2786 & 6.30259 \\
\hline Total & Primary School & 35 & 10.9429 & 3.07689 \\
Psychomotor & Secondary School & 72 & 11.0417 & 2.82562 \\
Skills & High School & 162 & 12.0617 & 2.36877 \\
& University, & 133 & 12.4812 & 2.23472 \\
& Postgraduate & 402 & 11.9204 & 2.53920 \\
\hline Total & Primary School & 35 & 19.8286 & 4.72469 \\
\multirow{5}{*}{ Self-Care Skills } & High School & 162 & 21.0988 & 3.96132 \\
& Secondary School & 72 & 20.6667 & 4.11113 \\
& University, & 133 & 21.7218 & 3.40533 \\
& Postgraduate & & & \\
& Total & 402 & 21.1169 & 3.91222 \\
\hline \hline
\end{tabular}

Regarding school readiness, according to the father's educational status, an increase in children's school readiness scores was observed as fathers' education level increases. The significance of this difference between the scores was tested by Kruskal-Wallis test.

The ANOVA results showing the relationship between father education level on children's perception of readiness, is given in the table below;

Table 18. ANOVA Test Results According to Father's Education Level

\begin{tabular}{|c|c|c|c|c|c|c|}
\hline & & $\begin{array}{l}\text { Sum of } \\
\text { Squares }\end{array}$ & $\mathrm{df}$ & $\begin{array}{l}\text { Mean } \\
\text { Square }\end{array}$ & $\mathrm{F}$ & Sig. \\
\hline \multirow{4}{*}{$\begin{array}{l}\text { Cognitive } \\
\text { Skills }\end{array}$} & Between & 4682,723 & 3 & 1560,908 & 9,019 & $*<, 000$ \\
\hline & Groups & & & & & \\
\hline & $\begin{array}{l}\text { Within } \\
\text { Groups }\end{array}$ & 68880,949 & 398 & 173,068 & & \\
\hline & Total & 73563,672 & 401 & & & \\
\hline \multirow[t]{3}{*}{ Affective Skill } & $\begin{array}{l}\text { Between } \\
\text { Groups }\end{array}$ & 668,742 & 3 & 222,914 & 5,814 & ,001 \\
\hline & $\begin{array}{l}\text { Within } \\
\text { Groups }\end{array}$ & 15260,054 & 398 & 38,342 & & \\
\hline & Total & 15928,796 & 401 & & & \\
\hline $\begin{array}{l}\text { Psychomotor } \\
\text { Skills }\end{array}$ & $\begin{array}{l}\text { Between } \\
\text { Groups }\end{array}$ & 134,106 & 3 & 44,702 & 7,258 & $*<, 000$ \\
\hline
\end{tabular}




\begin{tabular}{cccccc} 
Within & 2451,346 & 398 & 6,159 & & \\
Groups & & & & & \\
Total & 2585,453 & 401 & & & \\
\hline $\begin{array}{l}\text { Self-Care Skills } \begin{array}{l}\text { Between } \\
\text { Groups }\end{array} \\
\text { Within }\end{array}$ & 6016,407 & 3 & 40,469 & 2,677 &, 047 \\
Groups & & & & & \\
Total & 6137,505 & 401 & & & \\
\hline \hline & $* \mathrm{p}<0,05 H_{0}: \mu_{1}=\mu_{2} \ldots \mu_{n}$ & & & \\
\hline
\end{tabular}

When the table above is analyzed, it can be seen that the hypothesis, which claims that the difference between the group averages in terms of father's education level is statistically insignificant, can be rejected in all dimensions ( $p<0.05)$. Therefore, it can be said with $95 \%$ confidence that the education level of the father is statistically significant on the perceptions of children about their readiness.

In order to determine from which groups causes the difference between the group averages according to the father's education status, the results of the Scheffe Post-Hoc test that is conducted are given in the table below;

Table 19. Scheffe Post-Hoc test results according to Father's Education Level 95\% Confidence

Mean

Dependent (I) Father's (J) Father's Difference Std. Lower Upper

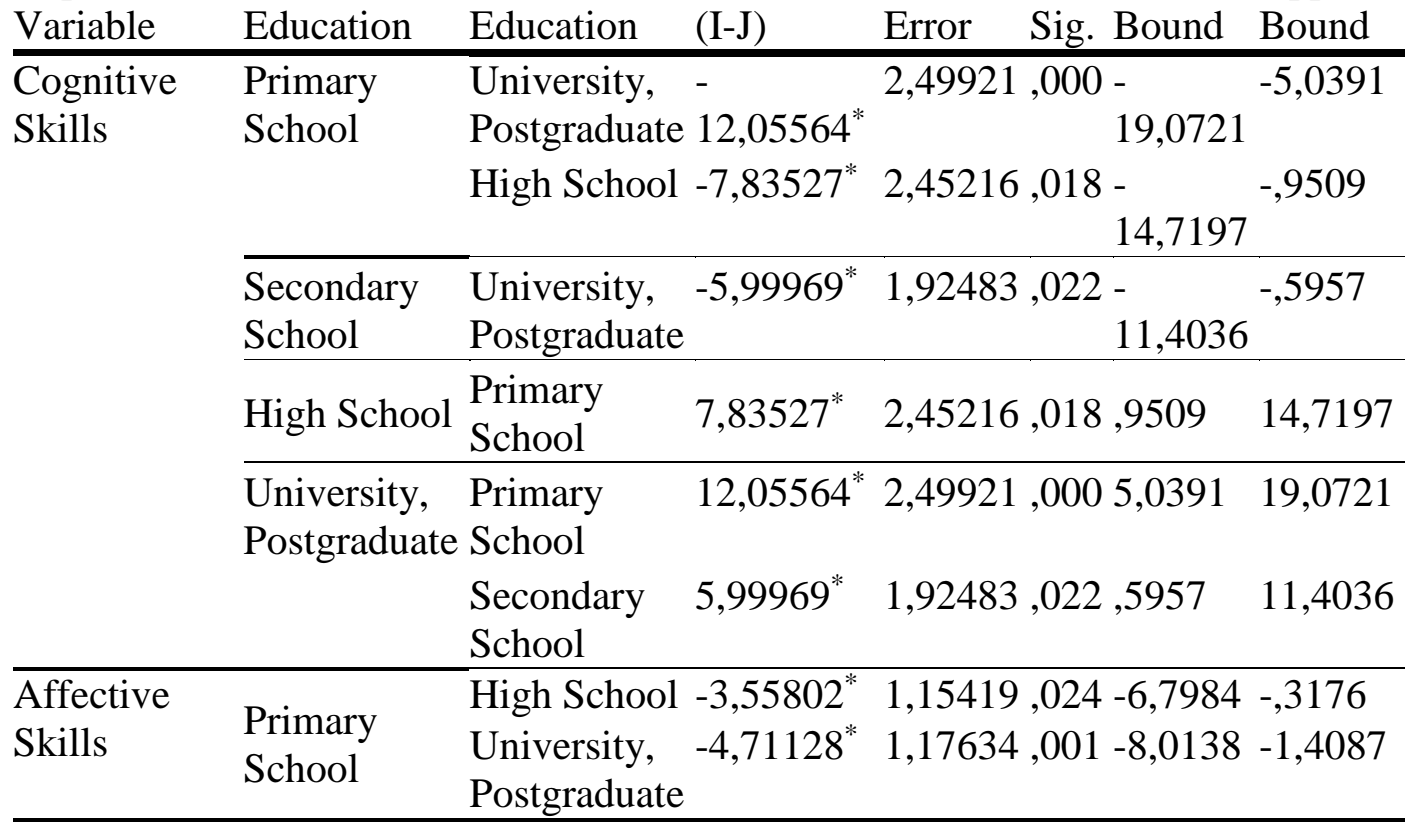




\begin{tabular}{llllll}
\hline High School Primary & $3,55802^{*}$ & $1,15419,024,3176$ & 6,7984 \\
\hline $\begin{array}{l}\text { School } \\
\text { Oniversity, }\end{array}$ & $\begin{array}{l}\text { Primary } \\
\text { Postgraduate School }\end{array}$ & $4,71128^{*}$ & $1,17634,001$ & 1,4087 & 8,0138 \\
\hline
\end{tabular}

Psychomotor Primary $\quad$ University, $-1,53835^{*}, 47147,015-2,8620-, 2147$

Skills

School Postgraduate

Secondary High School $-1,02006^{*}, 35152,039-2,0069-, 0332$

School University, $-1,43954^{*}, 36312,001-2,4590-, 4201$

Postgraduate

\begin{tabular}{lllll}
\hline High School Secondary & $1,02006^{*}, 35152,039,0332$ & 2,0069
\end{tabular}

School

University, $\quad$ Primary $\quad 1,53835^{*}, 47147,015,2147 \quad 2,8620$

Postgraduate School

Secondary $1,43954^{*}, 36312,001,4201 \quad 2,4590$

School

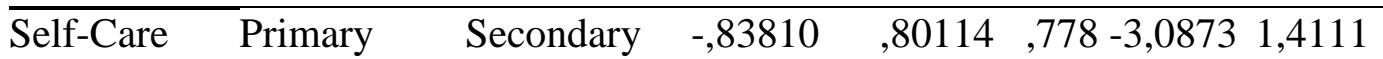

Skills School School

High School -1,27019 ,72470 ,382-3,3048,7644

University, -1,89323, 73860, 089-3,9668,

Postgraduate

Secondary $\quad$ Primary $\quad, 83810 \quad, 80114,778-1,41113,0873$

School School

High School -,43210 , 55068 ,893-1,9781 1,1139

University, - $-1,05514,56885,330-2,6522,5419$

Postgraduate

\begin{tabular}{lllll}
\hline High School Primary & 1,27019 &, 72470 & $382-, 7644$ & 3,3048
\end{tabular}

School

Secondary $\quad$,43210 , 55068 ,893-1,1139 1,9781

School

University, -,62304 45493, 599-1,9002,6542

Postgraduate

University, Primary $1,89323 \quad, 73860,089-, 1804 \quad 3,9668$

Postgraduate School

Secondary $\quad 1,05514 \quad, 56885 \quad, 330-, 5419 \quad 2,6522$

School

High School ,62304 45493, 599-,6542 1,9002 
When the table above is examined, it is seen that the source of the difference in terms of cognitive and affective skill perceptions according to the education level of the father consists of primary school graduates. It can be said that students whose fathers are primary school graduates have lower school readiness in terms of cognitive and affective skills. When the students' level of school readiness in terms of psychomotor skills was examined, it was determined that students whose fathers were primary and secondary school graduates were better than those whose fathers were high school and university graduates.

When Table 19 is examined for father education level, according to cognitive skills sub-dimension; university education level is creating significant difference level from other education levels. For Affective skills primary school education level is creating significant difference level from other education levels. For Psychomotor skill sub-dimension, secondary school level is creating significant difference from other education levels. But there are no significant difference for Self-care skill according to father's education levels.

Finally, the results of the test analyzing the effect of father's employment status on relevant variables are shown below;

Table 20. Descriptive Statistics for the Sub-dimensions According to Student's Fathers Employment Status

\begin{tabular}{lllll}
\hline \hline Dimensions & $\begin{array}{l}\text { Father's } \\
\text { Employment }\end{array}$ & $\mathrm{N}$ & Mean & Std. Deviation \\
\hline Cognitive Skills & $\begin{array}{l}\text { Non- } \\
\text { employed } \\
\text { Employed }\end{array}$ & 16 & 596.0000 & 19.33218 \\
& Non- & 16 & 68.0777 & 13.16150 \\
\hline Affective Skills & $\begin{array}{l}\text { employed } \\
\text { Employed }\end{array}$ & 386 & 32.4715 & 6.11113 \\
\hline Psychomotor Skills & $\begin{array}{l}\text { Non- } \\
\text { employed } \\
\text { Employed }\end{array}$ & 16 & 9.9375 & 3.10846 \\
\hline Self-Care Skills & $\begin{array}{l}\text { Non- } \\
\text { employed }\end{array}$ & 16 & 12.0026 & 2.48371 \\
\hline \hline
\end{tabular}

As can be seen in Table 20, the school readiness levels of the children whose fathers are working are higher than the children whose fathers are not working. 
Table 21. Mann-Whitney-U Test Results according to the Father's

Employment status

\begin{tabular}{lllll}
\hline \hline & Cognitive Skills & Affective Skills & Psychomotor Skills & Self-Care Skills \\
\hline Mann-Whitney U & 2145.000 & 2049.500 & 1823.000 & 2171.500 \\
$\mathrm{Z}$ & -2.088 & -2.302 & -2.864 & -2.091 \\
$\mathrm{p}$ & $.037^{*}$ & $.021^{*}$ & $.004^{*}$ & $.037^{*}$ \\
\hline \hline
\end{tabular}

Regarding Table 21, the zero-hypothesis claiming that the difference between the group means is statistically insignificant is rejected in cognitive skills, affective skills, psychomotor skills and self-care skills dimensions at a 95\% confidence level $(\mathrm{p}<0.05)$. According to this, it can be said that the father's employment status is statistically significant on all sub-dimensions of readiness scale. In other words, the children whose father is working start school more readily.

\section{Discussion}

In this study, primary school readiness of 402 children was analyzed. According to the results of the study, the average scores of the children were found to be high. In similar studies, children's school readiness levels have also been found to be high (e.g., Akay \& Ceylan, 2018; Alakoç Pirpir et al., 2016; Erkan and Kirca, 2010).

In this study, primary school readiness levels of the children were analyzed according to some variables, and significant differences were observed. One of these results is that the primary school readiness level of the children receiving preschool education was significantly higher than the children who did not receive preschool education. Similarly, in their research focusing on the effect of preschool education on children's school readiness, Ercan and Kurka (2010) concluded that there was a significant difference in favor of children receiving preschool education. Esaspehlivan (2006) examined the school readiness level of the children who have received preschool education and who have not. As a result of the study, it was found that the school readiness level of the children who received preschool education differed significantly from the children who did not receive preschool education. Alakoç Pirpir et al. (2016) found that there was a significant difference in favor of the children receiving preschool education in their research on the school maturity of primary school first-year pupils. The conclusion that preschool education variable has a positive effect on children's primary school readiness and school maturity (e.g., Arı \& Özcan, 2014; Erkan, 2011; Polat \& Yavuz, 2016; Unutkan, 2003) supports the result of the present 
research. In this context, the Preschool Education Program (MoNE, 2013), which aims to support all developmental areas of the children and prepare them for the next level of education, namely primary education, can be considered to be effectively implemented in educational institutions.

Another variable that predicted the primary school readiness of the children was age. It was found that 7-year-old children's primary school readiness was significantly different than 6-year-old ones $(p<0.05)$. Similar studies have shown that children's school readiness increases as the age of starting primary school increases (e.g., Akay \& Ceylan, 2017; Yoleri \& Tanış, 2014). On the other hand, in Arı and Özcan's study on the school maturity of first-year pupils, it was concluded that although the increase in age has positively affected the school maturity of children, it did not make a significant difference. Progress occurs in all development areas with the child's biological age, which is also considered as an important factor in getting the child ready for primary school.

Regarding the effect of gender of the child on primary school readiness, the mean scores of girls were slightly higher than boys in cognitive, psychomotor and self-care skills, but a significant difference $(p<0.05)$ was only seen in affective skills. In the study on primary school children. Yurdakavuştu (2012) concluded that girls' emotional intelligence and social skills levels were higher than boys. However, the review of the related studies showed that there was no significant difference according to gender since girls' scores were only slightly higher than that of the boys (e.g., Ar1 \& Özcan, 2014; Cinkılıç, 2009; Erkan, 2011; Yoleri \& Tanış, 2014).

The education level of the parents is among the variables that make a significant difference. The study showed that primary school readiness scores increase as the education level of the parents increases. Williams (2002) concluded that the school maturity level of the children increases as the education level of their parents increases. Studies showing that the increase in the education level of the parents positively affects children's school readiness, support this result (e.g., Alakoç Pirpir et al., 2016; Ar1 \& Özcan, 2014; Erkan \& Kirca, 2010; Martin, Ryan \& Brooks Gunn, 2010; Unutkan, 2003). It can be said that the child may be exposed to more educational support and interaction at home as the education level of the parents increases. Parents with higher levels of education may spend more time with their children, play games and be more responsive to their educational needs. Parents play a very important role in creating a literacy environment at home to support the child (Saracho, 2008).

The study also showed that the working status of the parents, which is an important factor in determining the socio-economic level of the family, is a variable that predicts the primary school readiness of the children. The primary school readiness level of the children whose father was working 
differed significantly in all dimensions compared to the children with a nonworking father. On the other hand, it was observed that the affective, psychomotor and self-care skills of the children whose mothers were working were slightly higher compared to children whose mothers did not work, and a significant difference was found in cognitive skills scores. It can be said that the socio-economic level of the children whose parents are working is better. Related studies show that the decrease in the socio-economic status of the family causes the child to be disadvantaged in being ready for school (e.g., Jeon et al., 2014; Ramey \& Ramey, 2004).

\section{Conclusion}

In this study, primary school readiness levels of the children were analyzed according to some variables, and significant differences were observed. One of these results is that the primary school readiness level of the children receiving preschool education was significantly higher than the children who did not receive preschool education. It was found that 7 -year-old children's primary school readiness was significantly different than 6-year-old ones ( $p<0.05)$. It has been determined that the children who have turned 7 in the first year of primary school have higher levels of school readiness than the six-year-old children. Regarding the school readiness of children according to gender, it is seen that girls' school readiness score is higher than boys. The study showed that primary school readiness scores increase as the education level of the parents increases. The primary school readiness level of the children whose father was working differed significantly in all dimensions compared to the children with a non-working father. On the other hand, it was observed that the affective, psychomotor and self-care skills of the children whose mothers were working were slightly higher compared to children whose mothers did not work, and a significant difference was found in cognitive skills scores.

\section{Recommendations}

As a result of this research, where school readiness of the children was examined, it was seen that the school readiness of the children was high, and their readiness levels were affected by preschool education, gender, age, education and working status of their parents. In order to increase children's primary school readiness, the followings are recommended: encouraging children to receive preschool education, waiting for the development of maturity level with age, further supporting boys in terms of affective skills, supporting families to minimize the negative effects that may arise from the education and working conditions of the parents.

Age should not be the only factor in starting children in primary school. In addition to the age factor, children's readiness, developmental 
characteristics and individual differences have to be considered as they start primary school. Preschool teachers who prepare children for primary school and classroom teachers who will undertake the education of 60-72 months old children should be trained on the transition characteristics of the target age group, basic needs and school maturity.

Primary School first grade environments should be designed in accordance with students' level of development and characteristics.

\section{Limitations and Directions for Future Research}

This research has expanded the scope of studies focusing on primary school readiness conducted in Turkey. But there were some limitations. It should be noted that primary school readiness of first-year pupils may vary in Turkey due to individual and cultural differences of the children. The study was limited to 402 children. It should be considered that in different regions of Turkey, different variables may affect children's development levels, as well as their primary school readiness levels. Therefore, it is important to work with bigger and larger samples in the future and include different variables that may be effective in primary school readiness.

\section{References:}

1. Akbağ, M. (2007). Gelişim psikolojisi kavramlarına giriş: Kavramlar, ilkeler, dönemler. M. E. Deniz (Ed.), Eğitim psikolojisi, (ss. 27-54). Ankara: Maya Akademi.

2. Alakoç Pirpir, D., Soydan, S., \& Angın, E. (2016). Birinci sınıf öğrencilerinin okul olgunluk düzeylerini yordayıcı bazı değişkenler. Pegem Atıf Indeksi, 489-504.

3. Baştuğ, M., \& Kurnaz, A. (2013). Birinci sınıfa hazır olmaya ilişkin ögretmen beklentileri. International Symposıum on Changes and New Trends in Education Sempozyumu'nda sunulmuş bildiri, Necmettin Erbakan Üniversitesi, Konya.

4. Bütün Ayhan, A. \& Aral, N. (2007). Bracken temel kavram ölçeğigözden geçirilmiş formunun altı yaş çocukları için uyarlama çalışması. Hacettepe Üniversitesi Ĕgitim Fakültesi Dergisi, 32, 42-51.

5. Britto, P. R. (2012). School readiness and transitions. New York: Education Section Programme Division, UNICEF. [Online]: Retrived on 10.11.2019, at URL: https://www.unicef.org/publications/files/CFS_School_Readiness_E_ web.pdf

6. Canbulat, A. N. K. \& Yıldızbaş, F. (2014). Okul öncesi ve sınıf öğretmenlerinin 60-72 aylık çocukların okula hazır bulunuşluklarına ilişkin görüşleri. Abant İzet Baysal Üniversitesi Ĕ̆itim Fakültesi Dergisi, 14(1), 33-50. 
7. Cinkılıç, H. (2009). Okul öncesi eğitimin ilköğretim birinci sınıf ögrencilerinin okul olgunluğuna etkisinin incelenmesi (Yüksek Lisans Tezi). Selçuk Üniversitesi, Konya.

8. Dinç, B.(2013). Okulöncesi eğitimden ilköğretime geçiş ve okul olgunluğu. F. Alisinanoğlu (Ed.). Illköğretime hazırlık ve ilköğretim programları, (ss.90-117). Ankara: Pegem Akademi Yayıncılık.

9. Erkan, S. (2011). Farklı sosyoekonomik düzeydeki ilköğretim birinci sınıf öğrencilerinin okula hazır bulunuşluklarının incelenmesi. Hacettepe Üniversitesi Eğitim Fakültesi Dergisi, 40, 186-197.

10. Erkan, S. \& Kırca, A. (2010). Okul öncesi eğitimin ilköğretim birinci sınıf öğrencilerinin okula hazır bulunuşluklarına etkisinin incelenmesi. Hacettepe Üniversitesi Ĕ̈itim Fakültesi Dergisi, 38, 94-106.

11. Esaspehlivan, M. (2006). Okul öncesi eğitim kurumuna gitmemiş 78 ve 68 aylık çocukların okula hazırbulunuşluklarının karşılaştırılması (Yüksek Lisans Tezi). Marmara Üniversitesi, İstanbul.

12. Ferguson, H. B. \& Bovaird, S., Mueller, M. P. (2007). The impact of poverty on educational outcomes for children. Podiatry Child Health, 12(8), 701-706.

13. Gündüz, F. \& Çalışkan, M. (2013). 60-66, 66-72, 72-84 aylık çocukların okul olgunluk ve okuma yazma becerilerini kazanma düzeylerinin incelenmesi. Turkish Studies, 8(8), 379-398.

14. Isaacs, J. B. \& Magnuson, K. (2011). Income and education as predictors of children's school readiness (Washington, DC: Brookings Institution).

19.11.2019

in http://www.brookings.edu/ /media/files/rc/reports/2011/1214_school _readiness_isaacs/1214_school_readiness_isaacs.pdf accessed from.

15. Işık, A. D., \& Akosmanoğlu, E., Bilir, A. (2015). Socio-cultural factors effecting first grade primary school students' reading success. Elementary Education Online, 14(4), 1327-1340.ta

16. Jeon, L., \& Cynthia, B. K., Eunhye, H. (2014). Family and neighborhood disadvantage, home environment, and children's school readiness. Journal of Family Psychology, 28(5), 718-727.

17. Koçyığıt, S. \& Saban, A. (2014). Birinci sınıf öğretmenlerinin ve ebeveynlerin görüşlerine göre okula hazır bulunuşluk. Kuramsal Ĕgitimbilim Dergisi, 7(3), 322-341.

18. Magnuson, K. A. \& Meyers, M. K., Ruhm, C. J. ve Waldfogel, J. (2004). Inequality in preschool education and school readiness. American Educational Research Journal, 41(1), 115-157.

19. Martin, A. \& Ryan, R. M., Brooks-Gunn, J. (2010). When fathers' supportiveness matters most: Maternal and paternal parenting and children's school readiness. Journal of Family Psychology, 24(2), 145155. 
20. MEB (İlköğretim kurumları yönetmeliğinde değişiklik yapılmasına dair yönetmelik). (2012). 22.11.2019 web:www.resmigazete.gov.tr accessed from.

21. MEB (İlköğretim kurumları yönetmeliğinde değiş̧iklik yapılmasına dair yönetmelik). (2019). 22.11.2019 web:www.resmigazete.gov.tr accessed from.

22. MEB. (2013). Okul öncesi eğitim programı. Ankara: MEB Yayınları.

23. Noel, A.M. (2010). Perceptions of School Readiness in One Queensland Primary School. Australasian Journal of Early Childhood, $35(2), 28-35$.

24. Oktay, A., \& Unutkan Ö.P. (2005). İlköğretime hazır oluş ve okul öncesi eğitimle ilköğretimin karşılaştırılması. Müzeyyen Sevinç (Ed.), Erken çocuklukta gelişim ve eğitimde yeni yaklaşımlar, (ss. 145-155). İstanbul: Morpa Kültür Yayınları.

25. Öztürk, E. \& Uysal, K. (2013). Primary School 1. sınıf öğrencilerinin okuma-yazma süreçlerinin takvim yaşı yönünden karşılaştırılması. Turkish Studies, 8(8), 1041-1054.

26. Polat, Ö., \& Yavuz, E. A. (2016). The relationship between the duration of preschool education and primary school readiness. Childhood Education, 92(5), 396-404.

27. Ramey, C. T. \& Ramey, S. L. (2004). Early learning and school readiness: Can early intervention make a difference? Merrill-Palmer Quarterly, 50(4), 471-491.

28. Saracho, O. N. (2008). A literacy program for fathers: A case study, department of curriculum and instruction. Early Childhood Education Journal, 35, 351-356.

29. Stacks, A.M. \& Oshio,T (2009). Disorganize data chmentand social skills as indicators of Head Start children's school readiness skills. Attachment \& Human Development. 11(2), 143-164.

30. Umek, L. M. \& Kranjc, S., Fekonja, U., \& Bajc, K. (2008). The effect of preschool on children's school readiness. Early Child Development and Care, 178(6), 569-588. doi:10.1080/03004430600851280

31. Unutkan, Ö. P. (2003). Marmara İlköğretim Hazır Oluş Ölçeğinin Geliştirilmesi ve Standardizasyonu (Doktora Tezi). Marmara Üniversitesi, İstanbul.

32. Vandell, D.L. \& Nenide, L., Winkle, S.J.V. (2006). Peer relationships in early childhood. In McCartney, K., \& Philips, D. (Eds.), Blackwell handbook of early childhood development (pp. 455- 470). Malden, MA: Blackwell.

33. Yavuzer, H. (2010). Ana-baba ve çocuk. Remzi Kitabevi, 21. Basım, İstanbul. 
34. Yazıc1, Z. (2002). Almanya ve Türkiye'de anaokuluna devam eden 60 76 aylar arasındaki türk çocuklarının dil gelişimi ile okuma olgunluğu arasindaki ilişkinin incelenmesi (Yüksek Lisans Tezi). Gazi Üniversitesi, Ankara.

35. Yoleri, S. \& Tanış, H. M. (2014). Primary School birinci sınıf öğrencilerinin okula uyum düzeylerini etkileyen değişkenlerin incelenmesi. Karabük Üniversitesi Sosyal Bilimler Enstitüsü Dergisi, 4(2), 130-141.

36. Yurdakavuştu, Y. (2012). İlköğretim ögrrencilerinde duygusal zekâ ve sosyal beceri düzeyleri (Doktora Tezi). Dokuz Eylül Üniversitesi, Eğitim Bilimleri Enstitüsü, İzmir.

37. Yörükoğlu, A. (1993). Çocuk ruh să̆gl̆ğı. İstanbul: Özgür Yayın Dağıtım. 